\title{
Patriots at the Periphery: David Nassy, the French Revolution, and the Emancipation of the Dutch Jews
}

\author{
Sina Rauschenbach*
}

After the foundation of the Batavian Republic and the emancipation of nonCalvinist Christians, Dutch Patriots were torn by the question whether Dutch Jews, too, should be emancipated. ${ }^{1}$ While defenders of emancipation proclaimed that discussions were superfluous because Jews were already part of the declaration of human rights, adversaries stressed that Jews formed a "separate nation" and that their emancipation would endanger national unity. Human rights and civil rights were to be distinguished. ${ }^{2}$ Discussions reached their peak on 26 March 1796, when members of Felix Libertate, a Dutch society of Jewish (and non-Jewish) sympathizers with the French Revolution, ${ }^{3}$

* I would like to thank Yosef Kaplan for inviting me to his wonderful conference in Jerusalem. I am grateful to Michael Silber for sharing with me some of his thoughts and materials on Jewish military service, to Maria Seidel for helping with the first version of this chapter and first translations of several quotations, and to Sharon Assaf for her careful editing of the final version. The final translations are mine if not otherwise indicated.

1 M.E. Bolle writes: "In het eerste jaar van de Bataafse Republiek was de positie der Joden bij de patriotten een der belangrijkste onderwerpen van discussie." (De opheffing van de autonomie der kehillot in Nederland 1796 [Amsterdam: Systemen Keesing, 1960], 111). For a recent survey and a classical study of the Dutch context, see Joost Rosendaal, De Nederlandse Revolutie: Vrijheid, volk en vaderland, 1783-1799 (Nijmegen: Uitgeverij Vantilt, 2005), and Simon Schama, Patriots \& Liberators: Revolution in the Netherlands, 1780-1813 (London: Harper Perennial, 2005 [1977]).

2 For a summary of those and other arguments, see Salvador E. Bloemgarten, "De Amsterdamse Joden gedurende de eerste jaren van de Bataafse Republiek, 1795-98," Studia Rosenthaliana 1/2 (1967): 45-70, here 45-61.

3 Felix Libertate was established on 6 February 1795. For details, see Bolle, De opheffing, esp. 83-118. Also see Bloemgarten, "De Amsterdamse Joden," Studia Rosenthaliana 1, no. 1 (1967): 66-96; Herbert I. Bloom, "Felix Libertate and the Emancipation of Dutch Jewry," in Essays on Jewish Life and Thought Presented in Honor of Salo Wittmayer Baron, ed. Joseph L. Blau et al. (New York: Columbia University Press, 1959), 105-22; Rena G. Fuks-Mansfeld, "Enlightenment and Emancipation, from c. 1750 to 1814," in The History of the Jews in the Netherlands, ed. Johan C.H. Blom, Rena G. Fuks-Mansfeld, and Ivo Schöffer (Oxford: Littman Library of Jewish Civilization, 2002; first published in Dutch, Amsterdam: Balans, 1995), 164-91, esp. 178-85; Jozeph Michman, "Parnassijns en patriotten," Jaarboek Amstelodamum 75 (1983): 73-91,

(C) SINA RAUSCHENBACH, 2019 | DOI:10.1163/9789004392489_025

This is an open access chapter distributed under the terms of the prevailing CC-BY-NC License at the time of publication. 
submitted a petition claiming full citizenship and equality for all Jews. Three days later, the recently constituted National Assembly commissioned a committee that investigated the case and finally approved emancipation. ${ }^{4}$ After lengthy discussions, ${ }^{5}$ the National Assembly voted to grant Dutch Jews full civil rights on 29 September 1796. Three days later, their vote entered into vigor, and all Dutch Jews became Dutch citizens. ${ }^{6}$

In spite of this political breakthrough, hate campaigns continued and left their mark well beyond $1796{ }^{7}$ Especially torn were Patriot societies founded in Dutch cities after 1795. Whereas societies in Rotterdam, Den Haag, Leiden, Leischendam and Haarlem welcomed Jews into their ranks, others rejected Jewish participation and even threatened to draw back from central meetings if Jews should be admitted. ${ }^{8}$ Among the opponents of Jewish emancipation was the Dordrecht society "For the Maintenance of Liberty and Equality." In the summer of 1795 , its members published a pamphlet that reproduced "classical" anti-Jewish arguments, pretended to prove the incompatibility of Jewish values with recent achievements of the French Revolution, and conjured the danger of thousands of German and East European Jews leaving their countries and settling in the Netherlands. The original version of the pamphlet is now lost. But knowledge about its content has come down to us by David de Isaac Cohen Nassy (1747-1806) and his Lettre theologico-politico morale sur les Juifs which will be at the center of this chapter. ${ }^{9}$ Nassy's Lettre, written in 1795 , translated into Dutch in 1798, and probably printed around 1800 , was a strong

and Michman, Dutch Jewry during the Emancipation Period: Gothic Turrets on a Corinthian Building (Amsterdam: Amsterdam University Press, 1995), 54-76.

4 For the members of the committee, see Bloemgarten, "De Amsterdamse Joden," Studia Rosenthaliana 1, no. 2 (1967): 47.

5 For parts of the debates of the National Assembly, see "The Debate on Jewish Emancipation (22-31 August 1796)," in The Jew in the Modern World: A Documentary History, ed. Paul Mendes-Flohr and Jehuda Reinharz (New York: Oxford University Press, 2011 [1980]), 131-44. For the complete text in the original Dutch version, see Dagverhaal der handelingen van de Nationaale Vergadering (The Hague: van Schelle en Comp., 1796), 2: 647-736.

6 For an English translation of the decree, see "Emancipation of Dutch Jewry (2 September 1796)," in The Jew in the Modern World, 144-45. For the original Dutch, see H.J. Koenen, Geschiedenis der Joden in Nederland (Utrecht: v. d. Post, 1843), 489-91.

7 Bloemgarten, "De Amsterdamse Joden," Studia Rosenthaliana 1, no. 2 (1967): 61-64.

8 Bolle, De opheffing, 111-14.

9 David Nassy, Lettre politico-theologico-morale sur les Juifs-Staatkundige, Godsdienstige, en Zedekundige Brief over de Joden (Paramaribo, s.n.). For a reprint and Nassy's French translation of the pamphlet, see ibid., n.p. The Dutch version of the pamphlet reads "Bericht van den Volks-Vergadering, tot behoud van Vryheid en Gelykheid, binnen Dordrecht." 
defense of Dutch Jews and a clear statement in favor of Jewish emancipation. ${ }^{10}$ According to Nassy, people of all religions should enjoy equal conditions, and they should only be judged on the basis of their virtues and merits. Nassy's treatise was one of many Jewish treatises against anti-Jewish calumnies in eighteenth-century Dutch debates. ${ }^{11}$ Interestingly however, Nassy was not a member of the Amsterdam or any Jewish community in the Batavian Republic. He never crossed the Atlantic, and he never visited Europe. David Nassy was a Surinamese Jew, descendent of an influential family of European settlers in the Guyanas and a proud American colonist. Among his publications were the important "Historical Essay on the Colony of Suriname" (Essai historique sur la Colonie de Suriname)12 and a "Memorial Concerning the Improvement of the Colony of Suriname" (Memoir sur l'amélioration de la Colonie de Suriname) which is no longer extant. ${ }^{13}$

Until now, the majority of studies on Nassy were based on his Essay, which has mainly been explored as a rich source for information about Jewish life in early modern Suriname. ${ }^{14}$ Recent research has also paid attention to Nassy's medical knowledge, ${ }^{15}$ as well as to his attitudes toward slaves and the institution

10 Nassy's Lettre has often been mentioned, but it has barely been analyzed. One obvious reason for this neglect is that copies are rare and difficult to find. For one of the few detailed studies of Nassy's Lettre, see Sigmund Seeligmann, "David Nassy of Suriname and his 'Lettre Theologico-Politico-Morale sur les Juifs', American Jewish Historical Society 22 (1914): 25-38. For the probable date of print, see ibid., 31.

11 For a general survey of different pamphlets published during the Dutch campaign, see Jacob da Silva Rosa, Bibliographie der Literatur über die Emanzipation der Juden in Holland (Frankfurt: J. Kauffmann, 1912). Interestingly, Nassy's Lettre is not listed in da Silva Rosa.

12 David Nassy, Essai historique sur la colonie de Suriname (Paramaribo [Amsterdam], 1788). For an English translation, see id., Historical Essay on the Colony of Surinam (1788), ed. Jacob R. Marcus and Stanley F. Chyet (Cincinnati: American Jewish Archives, 1974). For the purpose of this chapter, the English version (referred to as Essay) will be quoted. The French version (referred to as Essai) will be used in the case of important differences between both versions. Both versions consist of two tomes in one volume. In the French version, both tomes are separately numbered. Therefore, I include references to the respective tomes into my footnotes.

13 Nassy, Lettre, xviv, fn. H. Seeligmann reports that his efforts to find this memoir were not successful. See Seeligmann, "David Nassy of Suriname," 29.

14 For a prominent example, see Robert Cohen, Jews in another Environment: Surinam in the Second Half of the Eighteenth Century (Leiden: Brill, 1991). Also see Aviva Ben-Ur, "Archival Practices: The Creation of a Portuguese Jewish Identity," Kristòf 16, no. 2 (2015): 17-25.

15 Natalie Zemon Davis, "Een joodse arts in het achttiende-eeuwse Suriname," in Joden in de Cariben: Vier eeuwen joodse geschiedenis in Suriname en Curaçao (Jews in the Dutch Caribbean: Four Centuries of Jewish History in Suriname and Curaçao), ed. Julie-Marthe Cohen (Zutphen: Walburg Pers., 2015), 158-73. 
of slavery. ${ }^{16}$ The following study focuses on Nassy's Lettre and proposes a reading in the context of Nassy's colonial background and perception of Europe. This is important because Nassy did not only defend his Dutch coreligionists in a Christian anti-Jewish debate, he also took a clear position in an internal Jewish-Dutch controversy. However, this position was much more ambivalent than one might suspect, and it was surprisingly in-between the positions of the Dutch Jewish parties involved. In the conclusion of this chapter, it will be suggested that much of Nassy's argument was inspired by his American context and that we need to consider Nassy's speaking position as a non-European Jew to give him his full due.

The chapter falls into five sections. The first section introduces Nassy's earlier Essay and an interpretation in the context of Jewish Creole thought in the Americas. The three following sections are devoted to Nassy's Lettre and his ambivalence toward his Dutch Patriot coreligionists. In the second section, Nassy's Lettre is introduced. In the third section, the example of Jewish military service is used to underline partial agreements between Nassy and his Dutch Patriot coreligionists. In the fourth section, the example of the French Revolution serves to demonstrate the very same limits of those agreements. The final section contrasts Nassy's disillusion about France with his admiration for the Americas and his continuous challenge of European centers from the other side of the Atlantic.

David de Isaac Cohen Nassy and Surinamese Creole Thought

David de Isaac Cohen Nassy was born in Savannah, Suriname, in $1747 \cdot{ }^{17}$ In the eighteenth century, Suriname was a blossoming Dutch colony, and it was home to one of the most important Jewish communities in the Atlantic World with about forty percent of the "white" settler population being Jews. ${ }^{18}$ Between

16 See Natalie Zemon Davis, "David Nassy's 'Furlough' and the Slave Mattheus," in New Essays in American Jewish History: Commemorating the Sixtieth Anniversary of the Founding of the American Jewish Archives, ed. Pamela S. Nadell, Jonathan D. Sarna, and Lance J. Sussman (Cincinnati: American Jewish Archives, 2010), 79-93. Also see Wieke Vink, Creole Jews: Negotiating Community in Colonial Suriname (Leiden: Brill, 2010), passim, and Jonathan Schorsch, Jews and Blacks in the Early Modern World (Cambridge: Cambridge University Press, 2004), esp. 217-53.

17 For detailed biographical information, see R. Bijlsma, "David de Is. C. Nassy, Author of the Essai Historique sur Surinam," in The Jewish Nation in Surinam: Historical Essays, ed. Robert Cohen (Amsterdam: S. Emmering, 1982), 65-74.

18 For the most important monographs on the subject, see Cohen, Jews in another Environment, and Vink, Creole Jews. 
1770 and 1773, Nassy was the owner of a coffee plantation. Afterwards, he held different positions in the Sephardic community of Savannah, assumed representational functions at the Dutch colonial administration in Paramaribo, and was a practicing pharmacist and physician. He also figured among the founders of the Surinamese Sephardic literary society Docendo docemur in 1783. Together with his daughter and two slaves, Nassy left Suriname in 1792 and settled in Philadelphia where he was elected a member of the American Philosophical Society. ${ }^{19}$ Four years later, Nassy returned first to St. Eustatius in the Caribbean and then to Suriname. He died in 1806 and was buried at the Beit ha-Haim cemetery in Jodensavanne.

It is well known that Nassy's argument and thought were inspired by Christian Wilhelm Dohm (1751-1820) and his "On the Civil Improvement of the Jews" (Ueber die bürgerliche Verbesserung der Juden). In 1786, members of Docendo docemur got hold of a French copy of Dohm's treatise. ${ }^{20}$ After careful reading they decided to congratulate Dohm and suggest that the Prussian statesman should consider theirs as a model and exemplary case. According to them, the situation of the Jews in Suriname was completely incomparable with the situation of even the most privileged Jewish communities in Europe, and this contributed to the high level of morals and civilization among Surinamese Jews. ${ }^{21}$ Dohm responded enthusiastically: "The approbation which you attest to me, gentlemen, from the other end of the world is all the more consoling to me. May you enjoy the good fortune of not knowing, other than through the traditions of your ancestors, the manner in which your community is being vitiated in Europe! Your situation furnishes a convincing proof of my thesis, that the Jews are capable, like us, of being good citizens as soon as they are permitted to be."22

Dohm's letter included a request "to communicate to me some details on the advantages which your wise and enlightened government accords you."23 Nassy's Essay was written as a reply to this request. It was divided into two

19 For Nassy's years in Philadelphia, see Davis, "David Nassy's 'Furlough."”

20 See Nassy, Preface to Essay, 6. The translator was Jean Bernoulli. For a modern edition of this translation, see Christian Wilhelm Dohm, De la réforme politique des Juifs, ed. Dominique Bourel (Paris: Ed. Stock, 1984). For two important studies of Dohm in the context of eighteenth-century colonialism, see Jonathan M. Hess, "Sugar Island Jews? Jewish Colonialism and the Rhetoric of 'Civic Improvement' in Eighteenth-Century Germany," Eighteenth-Century Studies 32, no. 1 (1998): 92-100; and id., Germans, Jews, and the Claims of Modernity (New Haven: Yale University Press, 2002), 25-49.

21 Nassy, Preface to Essay, 6.

22 "Christian Wilhelm von Dohm to the Regents of the Portuguese Jewish Community of Suriname, 29 of January, 1787," in Nassy, Preface to Essay, 13.

23 Ibid. 
parts. The first part was dedicated to a chronological description of the history of Surinamese Jews in the context of the rise and development of the Western Sephardic diaspora. The second part followed the structure of early modern state descriptions and discussed important aspects of contemporary Surinamese history. Both parts became important contributions to the documentation of Jewish life in early modern Suriname and the Caribbean. But they are also highly illuminating for the study of eighteenth-century American Jewish thought, postcolonial counter-historiography, and early modern "writing back." As I have shown in another place, ${ }^{24}$ Nassy followed two different aims: on the one hand, he wanted to strengthen Jewish perspectives against Christian anti-Jewish calumnies and neglect. On the other hand, he wanted to clarify the position of Surinamese settlers against European arrogance and distortion. Nassy's antagonists were important chroniclers of Suriname and the Guyanas, ${ }^{25}$ as well as eminent figures and philosophers of the European Enlightenment, among them Voltaire (1694-1778), Guillaume Thomas Raynal (1713-1796), and the co-authors of Raynal's "Philosophical and Political History of the Settlements and Trade of the Europeans in the East and West Indies" (Histoire philosophique et politique des établissemens et du commerce des Européens dans les deux Indes). According to Nassy, their descriptions of Suriname either downplayed the contribution of Jews to the Colony or they neglected the needs and anxieties of Surinamese settlers, be they Jewish or Christian. In both cases, they transmitted pictures that were highly distorted. ${ }^{26}$ It was Nassy's outspoken effort in his Essay to correct the aforementioned descriptions and to rewrite their narratives. ${ }^{27}$

24 Sina Rauschenbach, "The Empire Writes Back: David Nassy and Jewish Creole Historiography in Colonial Suriname," in The Sephardic Atlantic: Colonial Histories and Postcolonial Concepts, ed. Sina Rauschenbach and Jonathan Schorsch (to be published in 2019). For the notion of "writing back," see Bill Ashcroft, Gareth Griffiths, and Helen Tiffin, The Empire Writes Back: Theory and Practice in Postcolonial Literatures (London: Routledge, 2002, first published in 1989). Ashcroft, Griffiths and Tiffin's book has received heavy criticism for its creation of "a grand theory of post-colonialism," but the notion of "writing back" is still prominent and clearly useful in well-defined and focused contexts. For Jewish writing back and counter-history in a European setting, see Susannah Heschel, "Revolt of the Colonized. Abraham Geiger's Wissenschaft des Judentums as a Challenge to Christian Hegemony in the Academy," New German Critique 77 (1999): 61-85.

25 Nassy criticizes, among others, Jacques Nicolas Bellin, Description géographique de la Guyane (Paris: Didot, 1763), and Jan Jacob Hartsinck, Beschryving van Guiana, of de Wilde Kust, in Zuid-America (Amsterdam: Tielenburg, 1770).

26 For the distorted pictures, see Nassy, Essay, 1: 43.

27 The English translation reads: "And in order to fulfil our purpose, we shall transcribe here the sketch which Monsieur de Raynal made in his Histoire Politique, and the authors whose works we have cited in this essay. In retracing what they wrote about the colony, we 
Nassy's Essay was a counter-history in a double sense: on the one hand, it was a Jewish contribution to a non-Jewish debate about Jewish history. On the other hand, it was a Creole contribution to a European discussion about the Americas, with the term "Creole" (criollo) referring to Europeans born in the colonies, to be distinguished from Europeans born in Europe (peninsulares). ${ }^{28}$ This use of "Creole" is common in Latin American Studies but it is not always congruent with other uses of "Creole," because it does not necessarily refer to descendants of African slaves and includes "white" cultures and peoples. ${ }^{29}$

In Spanish America, resistance against the privilege of peninsulares was a main motive for Creole identity building and struggles for independence. ${ }^{30}$ In Suriname, Creole Jews entirely identified with Jewish and non-Jewish Suriname-born (white) inhabitants with whom they shared experiences, problems, and thoughts. Sometimes their Creole identification was so strong that it conflicted with the larger concept of the Jewish Diaspora. In her important book about Surinamese Creole Jews, Wieke Vink writes: "A leitmotif in Surinamese Jewish history is the ongoing tension in Jewish communities

shall permit ourselves the liberty of suppressing, adding, recasting, and correcting what is there found to be exaggerated or defective, in accordance with the authority which truth devoid of all prejudice gives." Essay, 1: 121-22. For the original French version, see Nassy, Essai, 1: 191. For Nassy's reference to and criticism of Voltaire, see his Introduction to Essay, 15. For Nassy and Candide, see Essay, 1: 104.

28 For recent studies, see Juan M. Vitulli, and David Solodkow, eds., Poéticas de lo criollo: La transformación del concepto criollo en las letras hispanoamericanas (siglos XVI-XIX) (Buenos Aires: Corregidor, 2009).

29 See Edward Brathwaite, The Development of Creole Society in Jamaica, 1770-1820 (Oxford: Clarendon Press, 1971), xiv-xv. For a similar use in the field of Jewish Studies, see Vink, Creole Jews, 6-10, esp. 9-10. By contrast, Aviva Ben-Ur uses "Creolization" as "the fusion of European Jewish and black cultures and peoples." See Aviva Ben-Ur, "A Matriarchal Matter: Slavery, Conversion, and Upward Mobility in Colonial Suriname," in Atlantic Diasporas: Jews, Conversos, and Crypto-Jews in the Age of Mercantilism, 1500-180o, ed. Richard L. Kagan and Philip D. Morgan (Baltimore: Johns Hopkins University Press, 2009), 152-69, esp. 169. Nassy's use of the term "Creole" encompasses both meanings: on the one hand, Nassy describes himself as a "Creole" (Essay, 2: 164) and hence clearly refers to the white Surinamese population. On the other hand, he uses "Creole" to refer to Surinamese descendants of African slaves (ibid., 1: 68). For my argument, the first use is decisive.

30 For a most famous reference to Creole identity in the context of Latin American independences, see Simón Bolívar's statement that "[...] no somos indios ni europeos, sino una especie media entre los legítimos propietarios del país y los usurpadores españoles: [...] americanos por nacimiento y nuestros derechos los de Europa" (Simón Bolívar, Doctrina del libertador [Caracas: Ayacucho, 1979], 62). For a recent study in eighteenthcentury Creole historiography and identity building in Latin America, see Jorge Cañizares Esguerra, How to Write the History of the New World: Histories, Epistemologies, and Identities in the Eighteenth-Century Atlantic World (Stanford: Stanford University Press, 2001). 
between participating in a local environment and becoming ever more local and creole on the one hand, and a continued sense of belonging to a worldwide Jewish community on the other."31

Needless to stress that Surinamese Jewish identification with Creoles was mostly unilateral. Jonathan Schorsch has convincingly argued that "early modern Jews were not automatically white." 32 Nassy himself described Surinamese Jews as "a social group between Christians and slaves" (une classe intermediaire entre les Chrêtien[s], \& les Esclaves), ${ }^{33}$ and he never forgot to lament over the loss of solidarity among settlers in the course of the history and decline of the Colony. ${ }^{34}$ Nevertheless, Nassy's Creole identity in his Essay and his American perspective are impossible to miss. Good examples are Nassy's statement that inhabitants of eighteenth-century colonies were equal citizens and not any more "a class inferior to that of the inhabitants and the citizens of the mother country,"35 or his open vote for the strengthening of economic independence and for steps toward an American free trade agreement. ${ }^{36}$ Finally, Nassy is also a good example for Creole ambivalence. This is visible in his constant apologies for his lack of literary education and his "primitive" use of the French language. ${ }^{37}$ In his Lettre, Nassy repeated similar doubts, ${ }^{38}$ but he also continued to raise his voice and to counter European discourse.

\section{$2 \quad$ Nassy's Lettre politico-theologico Morale}

Nassy's Lettre politico-theologico morale sur les Juifs was divided into three sections: first, a "Preliminary Discourse" (Discours préléminaire), parts of which

\footnotetext{
31 Vink, Creole Jews, 265.

32 Schorsch, Jews and Blacks, 179. For a detailed discussion together with Jewish patterns of replies, see ibid., 166-216. In a similar manner, Aviva Ben-Ur speaks about a "not quite 'white' status" of Surinamese Jews. See her "Atlantic Jewish History: A Conceptual Reorientation," in Constellations of Atlantic Jewish History, 1550-1890: The Arnold and Deanne Kaplan Collection of Early American Judaica. A Companion Volume to an Exhibition Held in the Goldstein Family Gallery of the Kislak Center for Special Collections, Rare Books and Manuscripts, ed. Arthur Kiron (Philadelphia: University of Pennsylvania Press, 2014), 25-46, esp. 40.

33 Nassy, Lettre, 30, fn. 20.

34 In his Essay, Nassy stressed that Jewish and Christian planters had originally proven to be "true and useful colonists who ought to treat each other mutually as brothers." Essay, 1: $55^{-} 56$.

35 Nassy, Essay 2: 125 .

36 Ibid., 145 .

37 Nassy, Preface to Essay, 5. Also see ibid., 2: 164.

38 Nassy, Lettre.
} 
were only added upon publication of the Lettre around 180o; second, a reprint of the accusations of the so-called Dordrecht activists, and third, a lengthy discussion of and reply to each and every one of those accusations. In all sections, it was Nassy's aim to criticize the exclusion of Jews from recent reforms and to call for an end of prejudice and discrimination. According to Nassy, all people needed to be given the same chances. It was scandalous, "that the unknown origin or the low birth of a talented subject, that the unfortunate poverty of a virtuous man; that the difference of religion of persons who are equally distinguished by their merit and their dedication to the public good should be reasons to exclude them from certain professions and cause their being despised and regarded as useless to serve their Fatherland (Patrie)."39 Jews and nonJews were children of one and the same "Father State," and once that "Father State" shared his power among his children, he needed to share it equally. ${ }^{40}$ But the Batavian Republic and her colonies shamefully neglected their duty and continued to treat their Jews as if they did not belong. ${ }^{41}$ Their attitude was nurtured by the accusations brought against the Jews in treatises such as the Dordrecht pamphlet. Hence, Nassy felt obliged to defend his Dutch coreligionists and to prove, "1. That the religion of the Jews; their divine commandments; their rabbinic teachings and even their customs, are in no respect contrary to Justice, Humanity and Benevolence. 2. That one cannot justify on grounds of reason the refusal to admit the Jews to active civil rights and the enjoyment of full human rights; and that judging from what we know of their civil state in Europe and the Colonies till this day, their customs are in no sense inferior to those of the Christians." 42

39 “[...] que la naissance obscure ou médiocre d'un sujet à talens; que la pauvrété malheureuse d'un Homme vertueux; que la différence du culte de Personnes également distinguées par leur mérite, \& leur dévouement au bien public, soient des causes d'exclusion aux emplois, \& les fassent mépriser, \& même regarder comme inutiles au service de la Patrie [...]." Nassy, Lettre, xvi.

40 Nassy, Lettre, xlii. Interestingly, in his French translation of Dohm which Nassy used for his earlier Essay, Jean Bernoulli used the same words speaking about "cette distinction inhumaine et contraire à la bonne politique, qui sépare actuellement les malheureux circoncis des autres enfants de l'État" (Jean Bernoulli, "Additions du traducteur," in Dohm, De la réforme politique des Juifs, 107-12, here 107).

$41 \quad$ Nassy, Lettre, xlii.

42 "1. Que la Religion des Juifs; leurs commendemens divins; leurs Dogmes Rabiniques; \& leurs habitudes mêmes, ne sont nullement en contradicion avec la Justice, l'humanité, \& la bienveillance. 2. Qu'on ne peut justifier aux yeux de la raison, le refus d'admettre les Juifs aux droits de Citoyen actif, \& à la jouissance plenière de ceux de l'homme; \& qu'a juger de ce qu l'on connoit jusqu'a present de leur etat civil en Europe, \& dans les Colonies, leurs mœurs ne le cedent point à celles des Chretiens." Nassy, Lettre, 36 . 
In his reply to the calumnies of the Dordrecht pamphlet, Nassy proceeded argument by argument: ${ }^{43}$ contrary to the accusation that Jews separated themselves from other peoples and that they only formed temporary alliances when it served their interests, he contended that contemporary Jews considered Christians to be their brothers and that they lived with them as much as Christian societies supported and facilitated it (article 1). Contrary to the accusation that Jews were not reliable citizens nor partners, he stated that a more in-depth knowledge of history from biblical to modern times showed that opponents of the Jews used to present a distorted view of things and that Jews were no calumniators but victims of calumniations (article 2). Contrary to the accusation that Jews were political opportunists and mostly failing to defend Patriot movements, he explained that Jews needed to protect themselves from siding with political parties in situations of turmoil because they were the first to fall victim to false reproaches and uncontrolled violence (article 3). Contrary to the accusation that Jewish expectations of an earthly messiah and king were a threat to both, the declaration of human rights and republican governments, he argued that similar expectancies were only due to the condition of those who upheld them and that they would easily lose importance if the situation of the respective believers changed (article 4). Contrary to the fears that the emancipation of the Jews in the Netherlands would quickly result in a wave of Jewish refugees from German and Eastern European lands, he insisted that nothing similar had happened after the emancipation of the Jews in the United States, and that German and Eastern European Jews were too proud of their own intellectual and cultural heritage to leave their countries (article 5).

At the same time, Nassy continued, migration should not only be seen from a negative but also from a positive, demographical point of view. ${ }^{44}$ The history of the Netherlands had long proven that Jewish migration was highly important to the economic and military needs of the country. In Dutch colonies such as Suriname, things were even clearer, and Jewish migrants had become an indispensable part of their respective settler and merchant societies. Once again, Nassy expresses his pride with regard to American contributions to European blossoming and wealth:

The contribution of the Jews to the development of Suriname from the very times of Lord Whilloughby, is undeniable. And does the Colony of Suriname not owe its commerce only to the Jews? Who, like them, finds a

44 For the whole argument, see Nassy, Lettre, 96-104. 
big market for colonial goods in times of war [...]? Who, like them, keeps up commerce with the Americans, so useful and so indispensable for the interests and the needs of the Colony? Finally, who if not them, supports and increases public sales, who brings life into Suriname's commerce, in ceaseless movements, and who increases the sum of taxes? [...] Let us hence summarize [lit.: collect in one big bulk] all the respective requirements and all the advantages that the Jews bring to the state, and we will find that instead of evil it would be a great good for Holland and its American possessions, if the Jewish population there was increased and encouraged by all possible means. ${ }^{45}$

Nassy's arguments in his Lettre were based on a wide range of exempla from Jewish history, literature, and thought, touching upon biblical, rabbinical, medieval, and contemporary Judaism. According to Nassy, this was necessary because anti-Jewish polemicists did not distinguish between different times and places. Instead, they did not shy away from measuring rabbinical Jews living "in that far-off time, full of darkness and uncertainty" (dans ce temps reculé, rempli d'obscurité, \& d'incertitude) $)^{46}$ with their eighteenth-century Jewish counterparts. But this was highly unjust because no religion was static, and Jewish history—as any history—was subject to progress and change. Modern Jews were not to be blamed for the faults of their ancestors. Nor were Jews in the Netherlands or Suriname to be compared to Jews in Poland or Northern Africa. ${ }^{47}$

Once again, Nassy relied on Dohm, ${ }^{48}$ and he also returned to Dohm for his last intervention, that Jews were capable of being loyal soldiers and that it was

45 "Lessor que les Juifs, dès le temps même du Lord Whilloughby, ont donné à Surinam est incontestable. Eh! n'èst ce pas aux Juifs seuls que cette Colonie doit tout son Commerce? Qui, autant qu'eux, fait trouver en temps de Guerre, un grand debouché pour les denrées Coloniales [...]? Qui autant qu'eux entretient le Commerce avec les Americains, si utile, \& si indispensable pour les intérêts \& les besoins de la Colonie? Qui si ce ne sont pas eux enfin, soutient \& augmente les ventes publiques, qui mêt l'âme du Commerce de Surinam, en des mouvemens continuels, \& qui fait accroitre la somme des impôts? [...] Qu'on réunise donc en une seule masse, tous ces besoins respectifs, \& tous les avantages que les Juifs procurent à l'état \& l'on trouvera qu'au lieu de mal ce seroit un grand bien pour la Hollande, \& pour ses possessions en Amerique, que la population Juive, y-fut augmentée, \& encouragée par toutes sorte [sic] des moyens." Nassy, Lettre, 102-4.

$46 \quad$ Nassy, Lettre, 36.

47 Nassy, Lettre, 12.

48 For one out of several examples, see Nassy, Lettre, 9o. 
part of their civic duties to participate in armies and civil guards. ${ }^{49}$ Surprisingly, there was no mention of this topic in the Dordrecht pamphlet, as Nassy himself stated, ${ }^{50}$ but it was an important topic in contemporary discourse. It was one more example to highlight differences between Europe and the Americas, and it was also important for Nassy's earlier wish to express his solidarity with his Dutch Patriot coreligionists and their fight for emancipation.

\section{3}

Jews and the Military

Questions about Jewish military service and participation in civil guards played a prominent role in eighteenth-century debates about the emancipation of the Jews. ${ }^{51}$ Since the publication of Christian Wilhelm Dohm's Ueber die bürgerliche Verbesserung der Juden, Jews were encouraged to display their capacity for "civil improvement" and participate in the defense of their countries and towns. ${ }^{52}$ Anti-Jewish polemicists by contrast objected the supposed disloyalty and unreliability of Jews and hence their unsuitability as soldiers and citizens. ${ }^{53}$

But the question of Jewish military service not only served as an important argument in Christian debates about Jews, it also caused frictions among Jews themselves. One of the most hotly debated aspects was the supposed conflict between religious observance and military service on the Jewish Sabbath and

49 Nassy, Lettre, 104-20. For Nassy's reference to Dohm, see ibid., 106. Bernoulli mentioned discussions about Jews and the military in his French translation of Dohm which was Nassy's and his Surinamese coreligionists' source for their correspondence with the Prussian statesman. See Bernoulli, "Additions du traducteur," in Dohm, De la réforme, 112.

50 Nassy, Lettre, 104.

$5^{1} \quad$ For the European context, see Michael K. Silber, "From Tolerated Aliens to CitizenSoldiers: Jewish Military Service in the Era of Joseph II," in Constructing Nationalities in East Central Europe, ed. Pieter M. Judson and Marsha L. Rozenblit (New York: Berghahn, 2004), 19-36. For the Netherlands, see Bloemgarten, "De Amsterdamse Joden," Studia Rosenthaliana 1, no.1 (1967): 84-88.

$5^{2}$ See Christian Wilhelm Dohm, Ueber die bürgerliche Verbesserung der Juden, Erster Theil (Berlin and Stettin: Friedrich Nicolai, 1783), 145-58, as well as Christian Wilhelm Dohm, Ueber die bürgerliche Verbesserung der Juden, Zweyter Theil (Berlin and Stettin: Nicolai, 1783), esp. 222-46. One of Dohm's most famous anti-Jewish antagonists was Johann David Michaelis. See "Hr. Ritter Michaelis Beurtheilung des ersten Theils," in Dohm, Ueber die bürgerliche Verbesserung, Zweyter Theil, 31-71.

53 During the nineteenth century, anti-Semitic authors added pseudo-biological explanations of physical hindrances for Jewish military service and "service to the nation." For the turn of the argument from religion to pseudo-biology, see Sander Gilman, The Jew's Body (New York: Routledge, 1991), 39-59. For a recent monograph on the subject, see Derek Penslar, Jews and the Military: A History (Princeton, NJ: Princeton University Press, 2013). 
holidays. Interestingly, this conflict was often considered to be the same for Jewish soldiers and civil guards, even though the respective situations and requirements were highly different. ${ }^{54}$ In Habsburg Lands, Jewish leaders lamented over the moral decline and alienation of young men from their communities after the Reform Edicts of Joseph II and the first recruitment of Jewish soldiers in Galicia. After Joseph II's death, traditional rabbis pleaded for a restitution of community autonomy even at the cost of emancipation. ${ }^{55}$ Several maskilim, by contrast, welcomed the reforms and accepted their "logic of citizenship with its rights and obligations." ${ }^{56}$ Historian Tsila Rädecker writes: "In the maskilic invention of the Jewish citizen, it [i.e., military service] became an essential part of Jewishness. Proof of the compatibility of Jewish life and state citizenship focused especially on the issue of bearing arms on the Sabbath. The willingness of Jews to set aside the Sabbath's rest symbolized and functioned as a litmus test of Jewish loyalty to the state. The maskilim actively incorporated the military aspects of citizenship into their version of Jewishness." ${ }^{57}$

In the Northern Netherlands, the first Jews to participate in military service were seamen in the Fourth Anglo-Dutch War (1780-1784). ${ }^{58}$ Facing the threat of a French invasion in 1794, Amsterdam military commanders returned to Jewish community leaders and earlier quests for Jewish soldiers..$^{59}$ In the latter case, this was even more natural since Amsterdam Jews counted as loyal followers of the House of Orange and were said to have contributed to the defeat of the earlier Patriot Revolution in 1787.

However, after the capitulation of the Dutch government and the foundation of the Batavian Republic, the supposed Jewish loyalty to the Orangeist party

54 Michman, Dutch Jewry, 191. For an exception, see Zalkind Hourwitz, Apologie des Juifs en réponse à la question: est-il des moyens de rendre les Juifs plus hereux et plus utiles en France? (Paris: Quilleau, 1788).

55 Silber, "Jewish Military Service," esp. 30.

56 Ibid., 31. For the example of a maskil expressing his doubts about Jewish military service, see Saul Ascher, Bemerkungen über die bürgerliche Verbesserung der Juden veranlaßt, bei der Frage: Soll der Jude Soldat werden (S.l.: s.n., 1788).

Tsila Rädecker, "Making Jews Dutch: Secular Discourse and Jewish Responses, 1796-1848," (PhD diss., University of Groningen, 2015), 167.

$5^{8}$ Michman, Dutch Jewry, 184-202, esp. 184-86. This episode became prominent in Jewish and Christian defenses of Jewish military service. Jean Bernoulli referred to it in his "Additions du traducteur," in Dohm, De la réforme, 112. Dohm included it into the second part of his Ueber die bürgerliche Verbesserung, 239-40. Nassy mentioned it in the context of his defense of population growth and German-Jewish immigration to the Dutch Republic. See Nassy, Lettre, 100.

Michman, Dutch Jewry, 187. 
was exactly what made things difficult. ${ }^{60}$ When members of Felix Libertate petitioned for the admission of Jews into the new national guards, they started to lead a war on two fronts: on the one hand, they had to fight non-Jewish Dutch Patriots who rejected accepting Jews into national guards. On the other hand, they had to defend their petition against Jewish community leaders and rabbis who publicly stressed the incompatibility of Jewish military service with basic needs of halakhic obedience.$^{61}$ Finally, different decisions were taken in different places. In Amsterdam, members of the municipality declined the petition and Jews continued to be excluded from civil service until the foundation of the Kingdom of Holland and the rule of Louis Napoleon in 1806. Amersfoort, Den Haag, Groningen, Leiden, and Rotterdam municipalities chose the opposite option and Jews were accepted into national guards. ${ }^{62}$

Nassy was an ardent supporter of Jewish military service. Contrary to those who stated that Jews were useless to the service of the state and that halakhic obedience required that they "should let themselves be killed rather than take arms on their day of rest-not for their personal defense and still less for the defense of the places they live in,"63 Nassy insisted that there was no religious law that hindered Jews to participate in military enterprises. By contrast, Moses himself, "[...] author or voice of these [our] laws, this wise legislator whose political, civic and moral teachings are the base for almost all laws of the universe, was far away from giving a nation that he had torn away from slavery, and whose welfare depended on the conquests of all Palestine that he had in mind, and on the means he needed to conserve, defend and enlarge her, the order that one could call absurd, [namely] not to make War, nor to defend oneself on the day of Sabbath." ${ }^{64}$

6o Bloemgarten, "De Amsterdamse Joden," Studia Rosenthaliana 1, no. 1 (1967): 84-88, and Michman, Dutch Jewry, 184-202.

61 Bloemgarten, "De Amsterdamse Joden," Studia Rosenthaliana 1, no. 1 (1967): 85. For the Jewish Patriot response, see below, fn. 73 .

62 Michman, DutchJewry, 188. For Leiden and Rotterdam, see Bloemgarten, "De Amsterdamse Joden," Studia Rosenthaliana 1, no. 1 (1967): 85.

63 "[...] dévant se faire égorger plûtot que de prendre les Armes, dans ce jour de repos pour leur défense personnelle, encore moins pour celle des lieux qu'ils habitent [...]." Quoted in Nassy, Lettre, 104.

64 “[...] Auteur ou organe de ces loix, ce sage Legislateur dont les institutions Politiques, Civiles \& morales font la base de presque toutes les Loix de l'univers, etoit eloigné de donner à une Nation qu'il arracha de l'Esclavage, \& dont le bonheur dependoit des Conquêtes qu'il se proposoit de faire de toute la Palestine, \& des moyens qu'il lui fallait pour la conserver, la deffendre \& l'agrandir, l'ordre que l'on pourroit nommer absurde, de ne pas faire la Guerre, ni de se défendre le jour du Sabat." Nassy, Lettre, 106. Later in his Lettre, Nassy continued that Jews would even have stuck to the defense of their fatherland if there had been a religious law forbidding military service on the Sabbath. See Nassy, Lettre, 124. 
To prove his argument, Nassy adduced various examples, ranging from biblical times and antiquity to early modernity and his own world. With regard to contemporary Judaism, his most prominent examples were Amsterdam Jews defending Dutch Brazil between 1630 and 1654, Prague Jews encouraging their coreligionists to enlist among soldiers of Joseph II, and Surinamese Jews contributing to the military suppression of Maroon revolts in the Guyanas. ${ }^{65}$ Once again, South American examples played a prominent role. As early as in his Essay, Nassy dedicated various pages to descriptions of punitive expeditions of Surinamese plantation owners against fugitive slaves. ${ }^{66}$ In his Lettre, he repeated those descriptions and insisted that Surinamese Jews not only bore arms on the Sabbath but that they even did so on Yom Kippur: "[...] did they have any scruple to combat the black Maroons on the Sabbath? Was it not on the Day of Atonement, Kippur, that they defeated a considerable troop of these rebels under their Captain David Nassy? Did they not serve on Jewish holidays and Saturdays during the last war in 1781 and 1782 , [both] in the civil guard in Savannah under their Captain De Granada and in Paramaribo under Christian captains?"67

With regard to military service, Nassy's reference to the Americas was only natural: in Dutch and English colonies in South America and the Caribbean, Jewish settlers had been granted participation in local militia and military service ever since their first privileges in the seventeenth century. ${ }^{68}$ In the Dutch Guyanas, Jews had even been allowed to found their own civil guard which exempted them from fighting on the Sabbath. ${ }^{69}$ But according to Vink, Surinamese Sephardim had nevertheless decided on special occasions to bear

65 Nassy, Lettre, 110-12. For Prague, see Michman, Dutch Jewry, 186, and Silber, "Jewish Military Service," 21 (with bibliographical reference on $3^{2-} 33$, fn. 10). Obviously, Nassy referred to Rabbi Ezechiel Landau and his recommendation, also discussed in several statements by members of Felix Libertate. A good example is H.L. Bromet, Aan de Volks Societeit Felix Libertate. Gelykheid. Vryheid. Broederschap (22 March 1795), 7.

66 Nassy, Essay, 1: 86-88, and Vink, Creole Jews, 117-19.

67 " [...] se sont ils fait quelque scrupule de combattre les Negres Marrons au jour du Sabat? N'est ce pas au Kipur jour d'expiation, qu'ils vainquirent sous leur Capitaine David Nassy une Troupe considérable de ces rebelles? Pendant la dernière Guerre en 1781. \& 1782. n'ont ils pas tenu la Garde à la Savane sous leur Capitaine De Granada, \& à Paramaribo sous ceux de la Bourgeoisie Chrétienne, les jours de fêtes \& de Samedis." Nassy, Lettre, 112.

68 Penslar, Jews and the Military, 27. For the Dutch Guyanas, see Vink, Creole Jews, 134-38.

69 Jacob R. Marcus, The Colonial American Jew, 1492-1776, 3 vols. (Detroit: Wayne State University Press, 1970), 1: 147. For a reprint of the privileges granted to Jewish settlers in Cayenne (1659) and the English Guyanas (1665), see Nassy, Essay, 183-89. 
arms on Jewish holidays and their "religious laxity" had evoked a strong resistance among their Ashkenazic coreligionists. ${ }^{70}$

Nassy's plea for Jewish military service was much in line with the pleas of famous Dutch Jewish Patriots such as Hermanus Leonardus Bromet (1724-1812), Moses Salomon Asser (1754-1826), Hartog de Hartog Lemon (1755-1823), and Jacob Sasportas, all of whom Nassy mentioned and to whom he referred in his Lettre. ${ }^{71}$ Bromet, Asser, Sasportas, and Lemon were founding members of Felix Libertate in 1795. They authored the first petition for the admission of Jews to Dutch national guards, ${ }^{72}$ and they publicly protested against the official statement of Rabbis Daniel Cohen d'Azevedo (d. 1822) and Mozes Saul Löwenstamm (d. 1815) that Jews were not prepared for unconditional commitment to civic duties. ${ }^{73}$ After the split of the Amsterdam Ashkenazic Jewry in March 1797, they became founders of Adath Yeshurun, a new community that continued to fight for Jewish military service even though its larger purpose was to promote general reform and to defy old structures and hierarchies among Dutch Jews. ${ }^{74}$

Dutch Jewish Patriots not only resembled Nassy in defending Jewish military service. Similarly to Nassy, they also relied on West Indian examples to substantiate their argument: Especially Bromet, who had spent several years in Suriname, constantly referred to the Colony in his speeches and writings. ${ }^{75}$ Moses Salomon Asser for his part highlighted the influence of his Surinamese experience on Bromet's life and thought. ${ }^{76}$ Finally, Jewish military service and civil guards were also important topics in the so-called "Battle of Diskursn," a series of polemical pamphlets published by members of both communities between August 1797 and March 1798:77 Yankev, one of the most important characters in the Diskursn and a clear supporter of Adath Yeshurun (the so-called

$70 \quad$ Vink, Creole Jews, $188-92$.

71 Nassy, Lettre, lx. For the quotation, see below, fn. 79. Unfortunately, I have not been able to trace biographical data about this eighteenth-century Jacob Sasportas even though he signed many documents and petitions of Felix Libertate. Nassy also mentioned a certain M.M. Just, whom I have not been able to make out in Dutch biographical archives.

72 See their "Aan de Provisioneele Representanten van het Volk van Amsterdam," in Handelingen van de Municipaliteit der Stad Amsterdam (Amsterdam: Ter Stads Drukkerije, 1795), 239-40.

73 See "Request door het Joodsch Gezelschap den 12 Maart 1795 ingeleverd," in Handelingen van de Municipaliteit der Stad Amsterdam, 290-91.

74 See Michman, Dutch Jewry, 54-76.

75 An example is H.L. Bromet, Aan de Volks Societeit Felix Libertate. Gelykheid. Vryheid. Broederschap (March 22, 1795), 8. Also see Rädecker, Making Jews Dutch, 168.

76 See I.H.van Eeghen, "De Autobiografie van Moses Salomon Asser,"Jaarboek Amstelodamum 55 (1963): 130-65, esp. 144 .

77 For a detailed study and bilingual edition of several of the pamphlets, see Jozeph Michman and Marion Aptroot, eds., Storm in the Community: Yiddish Polemical Pamphlets 
naye kille), strongly defended the idea of Jewish recruitment and he also relied on "the West Indies" as a point of reference. ${ }^{78}$

Obviously, there was a broad consensus between Nassy and his Dutch Patriot coreligionists with regard to Jewish military service and national guards. At the same time, it would be misleading to read Nassy's Lettre as an unlimited support of Dutch Patriot Jews. Rather, Nassy seemed to change his opinion in the course of writing, translating and publishing his book. Two examples testify to this change: firstly, Nassy's reference to Bromet, Asser, Lemon, Sasportas, and Just was distanced, when he finished the introduction and justified the late publication of his Lettre. ${ }^{79}$ Secondly, his final judgment about the French Revolution in this introduction was also different from his earlier judgment, and it was completely irreconcilable with corresponding Patriot discussions in the Netherlands.

According to Bromet and his Dutch Patriot coreligionists, France and the French people had been harbingers of freedom. They had successfully implemented democracy on earth. They had proven to the world that the Platonic model was feasible and desirable. ${ }^{80}$ And they had implemented true liberty and equality being "an inherent and inalienable property that belongs equally to all human beings without difference" (een aangeboren en onvervreemdbaaren eigendom [...] aan alle Menschen, zonder onderscheid, even toebehoorende). ${ }^{81}$

According to Nassy, the single positive outcome of the French Revolution was the emancipation of the Jews. ${ }^{82}$ Apart from that, the Revolution had only

of Amsterdam Jewry, 1797-1798 (Cincinnati: Hebrew Union College Press, 2002). For military service, see ibid., 100, 108-10, 390-94, and 468-70.

78 Ibid., 107-8.

79 Nassy stated that his Lettre "contient des faits Historiques, des détails sur la politique, \& des éclaircissemens de plusieurs Dogmes Rabiniques \& autres, mal interprétés par l'ignorance, ou par la malice, que M.M. Just, Bromet, Asser, Lemmon, Sasportas, \&c. semblent n'avoir pas voulû les insérer dans les écrits récens qu'ils ont publié en faveur des Juifs [...]." Lettre, lx.

8o H.L. Bromet, Aanspraak, gedaan in de Societeit Felix Libertate op den 7 Maart 1795 (Amsterdam, 1795), esp. 13-14, 18.

81 Bromet, Aanspraak, gedaan in de Societeit Felix Libertate, op den 7 Maart 1795, 24.

82 In this regard, Nassy seemed to agree with the majority of Dutch Jews. See Rena G. FuksMansfeld, "Kezen en smousen in 1787: De moeizame verhouding tussen Patriotten en joden in Amsterdam in 1787," in De Nederlandse Revolutie?, ed. Theo S.M. van der Zee et al. (Amsterdam: De Bataafsche Leeuw, 1988), 134-46, here 145. 
triggered anarchy, lawlessness, chimerical dreams of democracy, inflationary usages of the term of "liberty," and misinterpretations of the concept of "equality." And Jews had suffered from it as others. ${ }^{83}$ In terms of clarity, Nassy's answers left nothing to be desired: "Pure democracy" (Democratie pure) was a Platonic dream, and any effort to implement it on earth was destined to anarchy and despotism. ${ }^{84}$ "Perfect equality" (égalite parfaite) was unjust and the only desirable equality was an equality of conditions. Nassy writes:

Yet the unjust idea is far from me to make the civil fortune consist of a perfect equality between all citizens of a state; this democratic chimaera does only exist in the brain of those rampant demagogues, who, in order to find their own luck, wind up the population with goals that are idealistic. Men are not equal with regard to their faculties. The virtues, the talents, the riches that are honestly acquired, the education, and finally the physical power, make human beings inevitably unequal between themselves. The welfare of the state requires that those citizens who are most useful for public affairs are the only ones employed by the public service, [that they are] the most honored and the most rewarded $[\ldots] .^{85}$

It was not privilege as such which needed to be abolished, it was inherited privilege: 86

Finally, "liberty," too, had recently turned into a fashionable word and been translated into a concept that led to anarchy and the end of social order. ${ }^{87}$

83 “La Revolution qu-y-a eu lieu, n'est point l'ouvrage des Juifs, toujours passifs, ils éprouvent les malheurs des secousses que les changemens de l'opinon publique, fait éprouver aux états; il seroit donc injuste de les priver de l'Avantage Idéal ou Réel, que la révolution promêt." Lettre, xlii.

84 “[...] quant à la Democratie pure, elle n'a jamais existé que dans le cerveau de Platon, \& les efforts qu'on a fait pour réaliser son rêve, ne conduiront qu'à l'anarchie, toujours suivie du despotisme." Nassy, Lettre, xxviii.

85 "Loin de moi cependant l'idee injuste, de vouloir faire consister le bonheur Civil, dans une égalite [sic] parfaite entre tous les Citoyens d'un état; cette chymère démocratique, n'existe que dans le cerveau de ces démagogues effrenés qui pour trouver leur propre bonheur, excitent le Peuple à des prétentions dont le but est idéal: les Hommes sont inégaux pour les facultes; les vertus, les talens, les richesses honnêtement acquises, l'éducation, la force Physique enfin, les rendent nécessairement inégaux entre eux; le bien de la Société veut que, les Citoyens les plus utiles à la chose publique, soient les seuls employés au service de l'état, les plus honorés, \& les mieux récompensés [...]." Nassy, Lettre, xii-xvi.

86 See the quotation in $\mathrm{fn} .39$.

87 Ibid., xviii, xxii, and xxiv. 
"True liberty" by contrast, was "the capacity of following one's reason and the laws [of a country], without running the risk of suffering from the tyranny of the stronger" (la faculté de pouvoir suivre la raison, \& les loix, sans courir le risque d'être tyranisé par le plus fort). ${ }^{88}$ According to Nassy, this liberty was no achievement of the French Revolution, and it had always been enjoyed by all people in Europe, except for slaves and subjects of the Ottoman Empire. ${ }^{89}$

As already emphasized, Nassy's statements were intended to object anti-Jewish accusations and prove that Jews were capable of sharing liberty, equality, and fraternity. But it is obvious that they were also defenses of traditional Jewish hierarchies, Sephardic privilege, and accusations against the same Dutch Patriot Jews with whom Nassy had sided in his earlier fight for Jewish military service and civil rights. ${ }^{90}$ Nassy's attack against his Dutch Patriot coreligionists reached its peak when he lamented over the bitter truth about ideal and reality:

France and maybe even Holland, just gave us striking examples of this unfortunate truth. Their system of liberty and equality is beautiful, and sublime without a doubt. Their principles are, according to me, comparable to those of our religions. They are only founded on nature and on moral derived from nature. But the vices of Man have corrupted and shattered everything. They have made us forget the basis of their principles [i.e., of the French Revolution and religion], only to remind us of their awful result: the religions, through the fanaticism, the ambition and the greed of many of their followers [....] seem to have only given birth to arrogant preachers, fanatics, wicked people and dangerous prejudice. The French Revolution, [...] through the measureless ambition, the wickedness and the vanity of a great number of sinister men who have seized

88 Ibid., $\mathrm{xx}$.

89 Ibid., xx. For Nassy on slaves and slavery, see Davis, "David Nassy's 'Furlough."”

9o For the defense of traditional Jewish hierarchies in the Dutch Republic and the few common interests of Patriots and Jews, see Fuks-Mansfeld, "Kezen en smousen." For recent research discussing Sephardic reservations toward emancipation, see Francesca Bregoli, Mediterranean Enlightenment: Livornese Jews, Tuscan Culture, and Eighteenth-Century Reform (Stanford: Stanford University Press, 2014), esp. 208-38. For the Caribbean context, see Laura Arnold Leibman and Sam May, "Making Jews: Race, Gender and Identity in Barbados in the Age of Emancipation," American Jewish History 99, no. 1 (2015): 1-26. 
upon the spirit of the Nation, seems to have only given birth to ambitious Demagogues, Cannibals, Anthropophagi, and great disasters. ${ }^{91}$

Nassy's words not only generated pictures of disillusion, desperation and fury, they also highlighted Nassy's ambivalent position between Dutch Patriots and traditional Jews. According to Nassy, there was no difference between powerobsessed human beings in politics or in religion. But given that Nassy's political adversaries were radical Dutch supporters of the Revolution and that Nassy's religious adversaries (with regard to Judaism) were traditional community leaders and rabbis from whom the Jews of his times were encouraged to break away in order to modernize, ${ }^{92}$ Nassy's statement was a double dissociation from both, the traditional majority of Dutch Jews and the Patriot minority. This double dissociation is surprising. Considering that the Lettre was written for a (hostile) Christian public and pretended to represent Nassy's Dutch coreligionists vis-à-vis a non-Jewish audience, it was even dangerous. The following section suggests that Nassy's American perspective and speaking position might be important clues for a better comprehension of his argument and thought.

\section{$5 \quad$ Patriots at the Periphery?}

As I have shown elsewhere, Nassy's Essay is an important example of counterhistoriography and Jewish Creole thought in eighteenth-century Suriname.

91 “...] la France, \& peut-être la Hollande même, viennent de nous donner des exemples frappans de cette malheureuse vérité; leur systême de liberté \& égalité, est beau, est sublime sans doute, leurs principes sont suivant moi, comparable à ceux de nos Religions, les uns \& les autres, ne sont fondés que sur la nature, \& sur la morale qui en dérive; mais les vices de l'Homme ont tout gâté, ont tout bouleversé; ils ont fait oublier les bases de leurs principes, pour ne nous rappeler que leur résultat affreux: Les Religions, par le fanatisme, l'ambition, \& l'avarice de plusieurs de leurs sectaires [...] semblent n'avoir enfanté que des prêtres insolens, des fanatiques, des scélérats, \& des dangéreux préjugés. La Revolution Françoise, [...] par l'ambition démésurée, la scélératesse, \& la vanité d'un grand nombre d'Hommes obscurs, qui se sont emparé de l'esprit de la Nation, semble n'avoir enfanté à son tour, que des Démagogues ambitieux, des Cannibales, des Antrophages, \& des grand malheurs." Nassy, Lettre, xxxii-xxxiv.

92 " [...] il faut donc s'en prendre je le repete, à la foule des ignorans, \& aux mauvaises traductions qu'on a de la Bible, des diverses habitudes imposées aux Juifs d'aujourd'hui." Nassy, Lettre, 116. Interestingly, Nassy based much of his argument on Johann David Michaelis who was supposed to be one of his most dangerous Christian adversaries. See above, fn. $5^{2}$. 
In the context of this counter-history, Nassy not only challenged Christian arrogance, power, and intolerance, he also criticized Amsterdam Jews and the European centers of the Western Sephardic diaspora. One example is Nassy's lament over the decadence of Amsterdam Sephardim and the "fewness of luminaries whom the community there was able to acquire [...] in the midst of so much religious liberty." ${ }^{\prime 93}$ Another example is Nassy's comment that Dutch (i.e., European) Sephardim, being victims of their Iberian socialization, had imported practices of intolerance from the Iberian Peninsula and that they had finally turned those practices against themselves and their most honorable community members. ${ }^{94}$

In his Lettre, Nassy reinforced his criticism of Dutch Jewish orthodoxy, superstition, and exclusivist policies while expanding it to Ashkenazic Jews. But he also took his distance from his Dutch Patriot coreligionists. In the early $1780 \mathrm{~s}$, Dutch Patriot Jews had shortly turned their eyes to the Americas and praised the American model for their purpose. However, they had quickly changed opinion and turned to France, as Asser recalled in his famous diary: "When the war between America and the English broke out, Bromet and I were very disposed toward America. From America [however], people turned to France and when disagreements broke out in the Netherlands [lit.: in these lands], the adherents of the French [lit.: the latter] closed lines with the Patriot party." ${ }^{\prime 95}$ Nassy followed the opposite direction. In his Lettre, France was only shortly considered an adequate model. ${ }^{96}$ Afterwards, it lost its positive function and turned into a great disillusion and a warning. Nassy's distance was even more

93 Nassy, Essay, 1: 22.

94 Ibid., 105. The examples Nassy adduced for Dutch Jewish intolerance were the ones of Uriel da Costa and Baruch Spinoza. In his Lettre, Nassy once again mentioned da Costa and Spinoza - together with Isaac de Pinto, Zacuto Lusitano and others as honored of the Portuguese nation. See Nassy, Lettre, 16.

95 "Den oorlog tusschen de Americanen tegen Engeland uitgebroken zijnde, waren Bromet en ik heel Americaansch gezind. Van Americaansch gezind wierd men Fransch gezind en bij het uitbarsten van de oneenigheden hier te lande, qualificeerden zich de laatstgemelden te behooren tot de patriotspartij." Quoted after van Eeghen, "De Autobiografie," 144. Later, Asser's son Carel described a similar development in his Récherches sur l'état des juifs. See [Carel Asser], "Recherches sur l'État des juifs en Hollande et Moyens provisoires de le réformer, eind Nov. of begin Dec. 1806," in Gedenkstukken der Algemeene Geschiedenis von Nederland von 1795-1840, Deel 5, Band 1, GS 11, 268-76, esp. 270. Also see Bloemgarten, "De Amsterdamse Joden," Studia Rosenthaliana 1, no. 1 (1967): 73.

96 In his earlier refusal of the Dordrecht pamphlet, Nassy mentioned America and France as his two models. See Nassy, Lettre, 24. His disillusion of the French Revolution was mostly expressed in his introduction which was written after 1796. See also Ibid., xii-xiv, fn. (A). 
striking because it coincided with his new self-description as a "Patriot." But Nassy was also explicit that his use of the term "Patriot" was a special one, and that it should in no way be wrongly interpreted. In one of the most expressive statements of his introduction, Nassy writes: "I confess that I am a Patriot, but a Patriot in a sense very different from that which is today given to this word: I love my Fatherland, despite the injustices it has often times administered me; true to my principles, I obey the laws of my country, I respect the rights of my neighbor and all while desiring that the era of necessary and useful changes on her Constitution, and on her customs will arrive, I loathe the efforts of those who desire changes, without consulting the interests of the majority of their fellow citizens." ${ }^{97}$ Given Nassy's distance from the French model and his Dutch Patriot coreligionists, his words come as no surprise. Instead of France, Nassy's Patriot thought was coupled with a new praise of "America" - with "America" now being the United States where Nassy lived during 1792 and 1796 and where he probably wrote the first version of his Lettre. According to Nassy, "America" was not only the place "where true equality reigns, [and] where all religions and religious sects are respected and have equal rights,"98 the American Constitution was also one of the main examples "that defied the wish of the Dordrecht society and other enemies of the Jews who do not want to recognize that they need to silence their interest as soon as reason and justice raise their voice."99 In the United States, Jews were fully integrated into their respective societies. They were married to Christians. ${ }^{100}$ They were granted entry into Academies and learned circles (as Nassy was granted entry in the American Philosophical Society), whereas "no Jew in Europe has ever received the honor to become a member of any Academy" (Aucun Juif n'a jamais pu avoir en

97 'J'avoue que je suis Patriôte, mais Patriôte dans un sens bien different de celui qu'on prête aujourd'hui à ce mot: J'aime ma Patrie, en dépit des injustices qu'elle m'a fait essuyer plusiers fois; fidelle [sic] à mes principes, j'obéis aux loix de mon païs, je respecte les droits de mon prochain, \& tout en désirant que l'époque des changemens nécessaires \& utiles à sa Constitution, \& à ses moeurs, soit arrivée, j'abhore les efforts de ceux qui désirent des changements, sans consulter les intérêts de la masse de leurs Concitoyens." Nassy, Lettre, xvi-xviii.

98 “...] où la vraie égalité règne, \& où toute les Religions, toutes les Sectes sont respectées, \& ont les mêmes droits." Nassy, Lettre, 94.

99 “[... qui s'opposent au desir du Club de Dordrecht \& des autres Ennemis des Juifs, qui veulent encore meconnoitre, que par tout où la raison \& la Justice élèvent leur voix, l'intérêt doit se taire." Nassy, Lettre, 20. A French translation of the American Constitutions, edited in Paris 1778, was in Nassy's library. See Cohen, Jews in another Environment, 223.

Nassy, Lettre, 42. 
Europe, l'honneur de dévenir membre d'aucune Academie). ${ }^{101}$ And they were admitted to the military and fought side by side with their non-Jewish Patriots, as should be added. ${ }^{102}$

Natalie Zemon Davis dedicated an impressive study to Nassy's North American experience and the impact of this experience on his thought about slavery and abolitionism. ${ }^{103}$ Nassy's Lettre suggests that the impact of Nassy's residence in Philadelphia was even stronger and went well beyond the subject of slavery and abolitionism. There are reasons for believing that even several positions in the Lettre that were not directly linked to "America" were inspired by Nassy's (North) American experiences and discussions. When Nassy published his Essay, he could proudly state that the situation of the Jews in Suriname was highly privileged. ${ }^{104}$ When he published his Lettre, the French Revolution had changed political landscapes in Europe and it had promoted the emancipation of several European Jewries. As a consequence, Surinamese privilege paled and the importance of Surinamese Jews declined. It was Nassy's special privilege that he could enlarge his "American experience" and compensate losses by the adoption of a different model and the finding of new examples in the United States.

Further analysis is required to confirm the assumption that much of Nassy's thought in his Lettre was in fact taken from the recently founded United States. For our purpose it is important to focus on Nassy's attitude toward Europe and his European coreligionists. Given that Nassy tended to think in continental terms, ${ }^{105}$ it is adequate to state that his Essay and his Lettre were both written from an American perspective, and that they were both meant to challenge the dichotomy between Europe and the Americas, center and periphery, in spite of the completely different settings that Nassy faced in 1788 and in 1795 (or in 1798). This challenge was closely connected to the difficult relationship between Jewish Creole Thought/Patriotism on the one hand and Jewish

\footnotetext{
101 Ibid., 30, fn. (20).

102 Rezneck, Samuel, Unrecognized Patriots: The Jews in the American Revolution (Westport, CT: Greenwood Press, 1975). For the early struggle of Asser Levy to enroll in the militia of New Amsterdam after the settlement of Sephardic refugees in the Dutch city, see Howard B. Rock, Haven of Liberty: New York Jews in the New World, 1654-1865 (New York: New York University Press, 2015 [2012]), 82-84.

103 Davis, "David Nassy's 'Furlough'."

104 See above, fn. 21.

105 For examples showing that Nassy tended to think in continental terms, see above, fn. 35 and 36 . It should be added that Nassy's continental thought is anything but surprising if we consider that Sephardic networks in the early modern Atlantic naturally connected North and South American worlds.
} 
Diaspora identity on the other hand. As early as in his Essay, Nassy doubted the religious authority of Amsterdam's Jews in the Western Sephardic diaspora and designed himself as a "Creole."106 In his Lettre, Nassy only pretended to defend Dutch Jewish positions vis-à-vis Dutch Christian attacks. Actually, he ignored what Dutch Jews really thought and instead presented his own perspectives which were often different and highly influenced by Nassy's own American experience. With regard to the Jewish Diaspora, Nassy went even further and doubted its coherence as a whole. In one of his most absolute and radical statements, Nassy wrote that Jews belonged to the places that either adopted them or that legitimized their residence. As there was no country properly belonging to the Jews, there was no Jewish people. As there was no Jewish people, there was no Jewish nation. ${ }^{107}$ Once again, Nassy's position seemed to reflect the position of European Patriot Jews who insisted in a similar way that there was no Jewish people in the Diaspora and that fears about Jewish national movements were unjustified. ${ }^{108}$ But it can also be read as an American statement to be used against European superiority and dominance. At the same time, Nassy's attitude toward the Diaspora was much less clear than his aforementioned comments suggest. And it is obvious that Nassy, in spite of his ambivalence with regard to the subject, always continued to think in terms of transnational Jewish identities and solidarities, both in his Essay and in his Lettre. ${ }^{109}$

In the end, the difference between Nassy's approach to Europe in his Essay and his Lettre is a difference of self-confidence and "maturity."110 In his Essay, Nassy raised his voice as a Surinamese Jew in a European discourse

106 See above, fn. 29. For a recent study that discusses similar Creole attitudes in Joshua Hezekiah Decordova and the Jamaican context, see Stanley Mirvis, "Joshua Hezekiah Decordova and a Rabbinic Counter Enlightenment from Colonial Jamaica," in Reappraisals and New Studies of the Modern Jewish Experience: Essays in Honor of Robert M. Seltzer, ed. Brian M. Smollett and Christian Wiese (Leiden: Brill, 2015), 104-22. I am thankful to Jonathan Schorsch for this clue.

107 See Nassy, Lettre, 120.

108 For a prominent example in the context of Adath Yeshurun, see David Friedrichsfeld, De Messias der Jooden, of Republikeinische Gevoelens over Denzelven (The Hague: L. Cohen, 1796), esp. 10. Also see David Friedrichsfeld, Beleuchtungen über den Vortrag des Bür. v. Swinden bey den Stellvertretern des Volks von Holland in Dem Haag, die Stimmgerechtigkeit und das Bürgerrecht der Juden betreffend (Amsterdam, 1795).

109 For the Jews as a people, see Nassy, Lettre, xxxviii. For the Jews as a nation, see ibid., 16.

110 "Postcolonial literatures would apparently demonstrate their maturity when they stopped talking about themselves and got on with more 'universal' concerns." Ashcroft et al., The Empire Writes Back, $136-37$. 
on Suriname. Even though his intervention in this discourse was meant to serve as an example and comparison for European politicians, Nassy's authority was based on his Surinamese first-hand experience, and the subject to be discussed was Suriname. In his Lettre, Nassy's authority was also based on American firsthand experience but the debate in which Nassy interfered was concerned with Europe. In other words, whereas Nassy's Essay displayed American authority in American affairs, his Lettre displayed American authority in European affairs. This authority was valid because Nassy's American experience made him a distinguished commentator on things happening both inside and outside the Americas. Once we consider this important difference, it is obvious that the Lettre marks a new stage in Nassy's interaction with his European readers, and that it needs to be read as such to be given its full due.

The purpose of this chapter was to propose a new interpretation of Nassy's Lettre in the context of his earlier Essay, counter-historiography and Creole thought. Given that Nassy tended to express himself in continental terms, it was suggested that the Lettre continued Nassy's earlier practices of writing back and contesting European discussions from an American perspective. At the same time, there were important shifts of emphasis between both books. One shift that needed to be recalled was related to Nassy's models and examples, namely that Nassy's Essay relied mainly on Suriname while his Lettre was influenced by the United States. The other shift was related to the subject of content: Whereas Nassy's Essay was meant to correct European perceptions of Nassy's own country, the Lettre focused on Nassy's perceptions of European developments and debates. In Postcolonial Studies, non-European writings about European problems have been interpreted as a stage of "maturity" in the in the history of writing back. In the context of this chapter, Nassy's attitude to address a Christian public and to speak up for his Dutch coreligionists without subscribing to any of their positions could be seen in a similar way when compared to Nassy's earlier attitude in his Essay. Finally, Nassy's self-designation as a Patriot and his distance from Dutch and French Jewish (and non-Jewish) Patriots were used to highlight Nassy's speaking position and to suggest reconsidering his importance as a Jewish author writing from Suriname to Europe and challenging colonial dichotomies of center and periphery. 


\section{Bibliography}

Ascher, Saul. Bemerkungen über die bürgerliche Verbesserung der Juden veranlaßt, bei der Frage: Soll der Jude Soldat werden. S.l.: s.n., 1788.

Ashcroft, Bill, Gareth Griffiths, and Helen Tiffin. The Empire Writes Back: Theory and Practice in Postcolonial Literatures. London: Routledge, 2002.

[Asser, Carel]. "Recherches sur l'État des juifs en Hollande et Moyens provisoires de le réformer, eind Nov. of begin Dec. 1806." In Gedenkstukken der Algemeene Geschiedenis von Nederland von 1795-1840, Deel 5, Band 1, GS 11, 268-76. The Hague: Martinus Nijhoff, 1910.

Bellin, Jacques Nicolas. Description géographique de la Guyane. Paris: Didot, 1763.

Ben-Ur, Aviva. "Archival Practices: The Creation of a Portuguese Jewish Identity." Kristòf 16/2 (2015): 17-25.

Ben-Ur, Aviva. "Atlantic Jewish History: A Conceptual Reorientation." In Constellations of Atlantic Jewish History, 1550-1890: The Arnold and Deanne Kaplan Collection of Early American Judaica. A Companion Volume to an Exhibition Held in the Goldstein Family Gallery of the Kislak Center for Special Collections, Rare Books andManuscripts. Edited by Arthur Kiron, 25-46. Philadelphia: University of Pennsylvania Press, 2014.

Ben-Ur, Aviva. "A Matriarchal Matter: Slavery, Conversion, and Upward Mobility in Colonial Suriname." In Atlantic Diasporas: Jews, Conversos, and Crypto-Jews in the Age of Mercantilism, 1500-180o. Edited by Richard L. Kagan and Philip D. Morgan, 152-69. Baltimore: Johns Hopkins University Press, 2009.

Bijlsma, R. "David de Is. C. Nassy, Author of the Essai Historique sur Surinam." In The Jewish Nation in Surinam: Historical Essays. Edited by Robert Cohen, 65-74. Amsterdam: S. Emmering, 1982.

Bloemgarten, S.E. "De Amsterdamse Joden gedurende de eerste jaren van de Bataafse Republiek, 1795-98." Studia Rosenthaliana 1, no. 1 (1967): 66-96; 1, no. 2 (1967): 45-70, and 2, no. 1 (1968): 42-65.

Bloom, Herbert I. "Felix Libertate and the Emancipation of Dutch Jewry." In Essays on Jewish Life and Thought Presented in Honor of Salo Wittmayer Baron. Edited by Joseph L. Blau et al., 105-22. New York: Columbia University Press, 1959.

Bolívar, Simón. Doctrina del libertador. Caracas: Ayacucho, 1979.

Bolle, Menachem Eljakiem. De opheffing van de autonomie der kehilloth (joodse gemeenten) in Nederland 1796. Amsterdam: Systemen Keesing, 1960.

Brathwaite, Edward. The Development of Creole Society in Jamaica, 1770-1820. Oxford: Clarendon Press, 1971.

Bregoli, Francesca. Mediterranean Enlightenment: Livornese Jews, Tuscan Culture, and Eighteenth-Century Reform. Stanford: Stanford University Press, 2014.

Bromet, H.L. Aan de Volks Societeit Felix Libertate. Gelykheid. Vryheid. Broederschap (March 22, 1795). 
Bromet, H.L. Aanspraak, gedaan in de Societeit Felix Libertate op den 7 Maart 1795. Amsterdam: J.L. van Laar Mahuet, 1795.

Cañizares Esguerra, Jorge. How to Write the History of the New World: Histories, Epistemologies, and Identities in the Eighteenth-Century Atlantic World. Stanford: Stanford University Press, 2001.

Cohen, Robert. Jews in another Environment: Surinam in the Second Half of the Eighteenth Century. Leiden: Brill, 1991.

Dagverhaal der handelingen van de Nationaale Vergadering. The Hague: van Schelle en Comp., 1796.

Davis, Natalie Zemon. “David Nassy's 'Furlough' and the Slave Mattheus." In New Essays in American Jewish History: Commemorating the Sixtieth Anniversary of the Founding of the American Jewish Archives. Edited by Pamela S. Nadell, Jonathan D. Sarna, and Lance J. Sussman, 79-93. Cincinnati, OH: American Jewish Archives, 2010.

Davis, Natalie Zemon. "Een joodse arts in het achttiende-eeuwse Suriname." In Joden in de Cariben: Vier eeuwen joodse geschiedenis in Suriname en Curaçao (Jews in the Dutch Caribbean: Four Centuries of Jewish History in Suriname and Curaçao). Edited by Julie-Marthe Cohen, 158-73. Zutphen: Walburg Pers, 2015.

Dohm, Christian Wilhelm. De la réforme politique des Juifs [1782]. Edited by Dominique Bourel. Paris: Ed. Stock, 1984.

Dohm, Christian Wilhelm. Ueber die bürgerliche Verbesserung der Juden, Erster und Zweyter Theil. Berlin and Stettin: Friedrich Nicolai, 1783 .

Eeghen, I.H.Van. “De Autobiografie van Moses Salomon Asser." JaarboekAmstelodamum 55 (1963): 130-65.

Friedrichsfeld, David. Beleuchtungen über den Vortrag des Bür. v. Swinden bey den Stellvertretern des Volks von Holland in Dem Haag, die Stimmgerechtigkeit und das Bürgerrecht der Juden betreffend. Amsterdam: s.n., 1795 .

Friedrichsfeld, David. De Messias der Jooden, of Republikeinische Gevoelens over Denzelven. Den Haag: L. Cohen, 1796.

Fuks-Mansfeld, Rena G. "Enlightenment and Emancipation, from c. $175^{\circ}$ to 1814." In The History of the Jews in the Netherlands. Edited by Johan C.H. Blom, Rena G. FuksMansfeld, and Ivo Schöffer, 164-91. Oxford: Littman Library of Jewish Civilization, 2002.

Fuks-Mansfeld, Rena G. "Kezen en smousen in 1787: De moeizame verhouding tussen Patriotten en joden in Amsterdam in 1787." In De Nederlandse Revolutie? Edited by Theo. S.M. van der Zee et al., 134-46. Amsterdam: De Bataafsche Leeuw, 1988.

Gilman, Sander. The Jew's Body. New York: Routledge, 1991.

Handelingen van de Municipaliteit der Stad Amsterdam. Amsterdam: Ter Stads Drukkerije, 1795 .

Hartsinck, Jan Jacob. Beschryving van Guiana, of de Wilde Kust, in Zuid-America. Amsterdam: Tielenburg, 1770. 
Heschel, Susannah. "Revolt of the Colonized: Abraham Geiger's Wissenschaft des Judentums as a Challenge to Christian Hegemony in the Academy." New German Critique 77 (1999): 61-85.

Hess, Jonathan M. Germans, Jews, and the Claims of Modernity. New Haven: Yale University Press, 2002.

Hess, Jonathan M. "Sugar Island Jews? Jewish Colonialism and the Rhetoric of 'Civic Improvement' in Eighteenth-Century Germany." Eighteenth-Century Studies 32, no. 1 (1998): 92-100.

Hourwitz, Zalkind. Apologie des Juifs en réponse à la question: est-il des moyens de rendre les Juifs plus hereux et plus utiles en France? Paris: Quilleau, 1788.

Koenen, H. J. Geschiedenis der Joden in Nederland. Utrecht: v.d. Post, 1843.

Leibman, Laura Arnold, and Sam May. "Making Jews: Race, Gender and Identity in Barbados in the Age of Emancipation." American Jewish History 99/1 (2015): 1-26.

Marcus, Jacob R. The Colonial American Jew, 1492-1776. 3 vols. Detroit: Wayne State University Press, 1970.

Mendes-Flohr, Paul, and Jehuda Reinharz, eds. The Jew in the Modern World: A Documentary History. New York: Oxford University Press, 2011.

Michman, Jozeph. Dutch Jewry during the Emancipation Period: Gothic Turrets on a Corinthian Building. Amsterdam: Amsterdam University Press, 1995.

Michman, Jozeph. "Parnassijns en patriotten." Jaarboek Amstelodamum 75 (1983): 73-91.

Michman, Jozeph, and Marion Aptroot, eds. Storm in the Community:Yiddish Polemical Pamphlets of Amsterdam Jewry, 1797-1798. Cincinnati: Hebrew Union College Press, 2002.

Mirvis, Stanley. "Joshua Hezekiah Decordova and a Rabbinic Counter Enlightenment from Colonial Jamaica." In Reappraisals and New Studies of the Modern Jewish Experience: Essays in Honor of Robert M. Seltzer. Edited by Brian M. Smollett, and Christian Wiese, 104-22. Leiden: Brill, 2015.

Nassy, David. Essai historique sur la colonie de Suriname. Paramaribo [Amsterdam]: s.n., 1788.

Nassy, David. Historical Essay on the Colony of Surinam (1788). Edited by Jacob R. Marcus, and Stanley F. Chyet. Cincinnati: American Jewish Archives, 1974.

Nassy, David. Lettre politico-theologico-morale sur les Juifs-Staatkundige, Godsdienstige, en Zedekundige Brief over de Joden. Paramaribo: s.n, s.a.

Penslar, Derek. Jews and the Military: A History. Princeton, NJ: Princeton University Press, 2013 .

Rädecker, Tsila. "Making Jews Dutch: Secular Discourse and Jewish Responses, 17961848." PhD diss., University of Groningen, 2015.

Rauschenbach, Sina. "The Empire Writes Back: David Nassy and Jewish Creole Historiography in Colonial Suriname." In The Sephardic Atlantic: Colonial Histories 
and Postcolonial Concepts. Edited by Sina Rauschenbach and Jonathan Schorsch (to be published in 2019).

Rezneck, Samuel. Unrecognized Patriots: The Jews in the American Revolution. Westport, CT: Greenwood Press, 1975.

Rock, Howard B. Haven of Liberty: New YorkJews in the New World, 1654-1865. New York: New York University Press, 2015.

Rosa, Jacob da Silva. Bibliographie der Literatur über die Emanzipation der Juden in Holland. Frankfurt: J. Kauffmann, 1912.

Rosendaal, Joost. De Nederlandse Revolutie: Vrijheid, volk en vaderland, 1783-1799. Nijmegen: Uitgeverij Vantilt, 2005.

Schama, Simon. Patriots and Liberators: Revolution in the Netherlands, $1780-1830$. London: Harper Perennial, 2005.

Schorsch, Jonathan. Jews and Blacks in the Early Modern World. Cambridge: Cambridge University Press, 2004.

Seeligmann, Sigmund. "David Nassy of Suriname and his 'Lettre Theologico-PoliticoMorale sur les Juifs'” American Jewish Historical Society 22 (1914): 25-38.

Silber, Michael K. "From Tolerated Aliens to Citizen-Soldiers: Jewish Military Service in the Era of Joseph II." In Constructing Nationalities in East Central Europe. Edited by Pieter M. Judson and Marsha L. Rozenblit, 19-36. New York: Berghahn, 2004.

Vink, Wieke. Creole Jews: Negotiating Community in Colonial Suriname. Leiden: Brill, 2010.

Vitulli, Juan M., and David Solodkow, eds. Poéticas de lo criollo: La transformación del concepto criollo en las letras hispanoamericanas (siglos XVI-XIX). Buenos Aires: Corregidor, 2009. 